\title{
THE UNIFICATION EFFORTS IN EU CIVIL LAW
}

\author{
Eylem APAYDIN * \\ Deniz TEKIN APAYDIN**
}

\section{Abstract}

In the EU, it has been a prolonged idea that one day; the EU countries might share a common code regarding the civil law issues. A comprehensive civil code includes chapters on law of persons, family law, inheritance law, property law and the law of obligations (the law of contracts, torts and unjust enrichment) as witnessed by French and German Civil Codes. The solid efforts for this purpose were shown from the beginning of the 90's and have continued so far. Yet, nothing remarkable has been achieved. The article aims to analyse all the processes and efforts for the unification of civil law in the EU and demonstrate all the accomplishments and failures so far. The article, initially presents the competence of the EU to regulate the area, and then argues the 'pros' and 'cons' of the idea of a unified civil law; reveals the method to unify the civil law; and explores all the possible forms that the EU civil code could take. All the research done so far about the unification of the EU civil law have also been mentioned. Based on the findings revealed, this article concludes that it is difficult to produce a common civil code in the EU soon.

Keywords: Civil law, civil code, EU, unification of law.

\section{AB MEDENİ HUKUKUNDA BİRLEŞTİRME ÇABALARI}

$\ddot{O}_{z}$

Avrupa Birliği’nde, AB ülkelerinin bir gün medeni hukuk konularını kapsayan ortak bir kanuna sahip olmaları çok uzun zamandır devam eden bir idealdir. Fransız ve Alman Medeni Kanunlarından görüldügü üzere, kapsaml bir medeni kanun kişiler hukuku, aile hukuku, miras hukuku, eşya hukuku ve

\footnotetext{
* Assistant Professor at Kocaeli University, Faculty of Law, Civil Law Department, e-mail: eyapaydin@yahoo.com.

** Assistant Professor at Marmara University, Faculty of Law, Public International Law Department, e-mail: deniz.apaydin@marmara.edu.tr.
} 
borçlar hukuku (sözleşmeler hukuku, haksız fiil ve sebepsiz zenginleşme) konuları hakkında bölümler içerir. Bu amaca yönelik olarak ortaya konan somut çabalar 90'lı yilların başından başlayarak gösterilmiş ve bugüne kadar devam etmiştir. Maalesef, henüz kayda değer hiçbir şey başarllamamıştır. Bu çalışma, AB'de medeni hukukun birleştirilmesine yönelik tüm çabaları ve süreçleri analiz etmeyi ve bugüne kadar ki bütün başarıları ve başarısılıkları gözler önüne sermeyi amaçlamaktadır. İlk olarak AB'nin böyle bir yasama faaliyetinde bulunması konusundaki yetkisini ele alan bu çalışma, daha sonra birleşmiş bir medeni hukuk düşüncesine lehte ve aleyhte olan hususlarl tartışmakta, medeni hukuku birleştirme metotlarını sunmakta, AB medeni kanununun alabileceği muhtemel $A B$ normu formlarını incelemektedir. $A B$ medeni hukukunun birleştirilmesine yönelik bugüne kadar yapılmış bütün araştırmaları da anmaktadır. Bu çalışma, ortaya konan bulgular neticesinde, yakın bir zamanda, AB'de ortak bir medeni kanun yapmanın zor olduğu sonucuna varmaktadir.

Anahtar Kelimeler: Medeni hukuk, medeni kanun, AB, hukukun birleştirilmesi.

\section{Introduction}

\section{Scope and Aim}

The aim of this article is to analyse all the process and efforts made so far for the unification of civil law in Europe. A unified European civil law is a dream for some, and a goal for some, to pursue decisively. We knew that once upon a time in Europe, there was a common law, ius commune, based on Roman law. The same principles of contract law as law of merchant, applied to the all transactions at all the harbours, fairs, bazaars and markets of Europe. After the French revolution and the rising of nationalism, national civil codes were introduced and replaced the old law based on Roman law. ${ }^{1}$ It is believed that in that modern age this can also be achieved by a unified civil code in Europe.

The idea for the European civil code (hereinafter ECC) was shined with the foundation of the EU. The EU has always urged and financially supported academics and institutions to work on drawing unified principles of private law in Europe. This article summarizes the historical process of the unification of European civil law and evaluates the idea itself to analyse its feasibility and achievability within the EU law, and reaches to a final conclusion about it. This

\footnotetext{
${ }^{1}$ For the chronology see Apaydın, E. (2013) "Satım Hukuku Özelinde Uluslararası Sözleşme Hukukunun Birleştirilmesi Çalışmalarının Kronolojisi”, (Prof.Dr. Aydın Zevkliler'e Armağan), Journal of Yasar University, 8(9): 201-74.
} 
study, is also an endeavour to present the collection of efforts of various study groups, commissions, EU institutions and scholars. With this goal in mind, the authors have adopted an approach to stay true to the original texts as much as possible, thus included various direct citations in their paper.

In this article, initially, the history of unification initiatives of civil law in Europe will be presented and the competence of the EU for such a unification effort will be discussed under current EU law. Secondly, all the arguments in favour and against the creation of a unified civil code in Europe will be discussed from various perspectives. Thirdly, the legal instruments available in EU law for enacting a legislative act relating to an ECC will be explored, taking into account the peculiarities and capacity of each norm type. Next, all the legal texts produced so far for the unification of ECC will be examined and their value will be evaluated in terms of a comprehensive civil code. Then, all the research done and the ones that are still in progress will be mentioned. Finally, our verdict on the future of the ECC will be submitted in the last section of this article.

\section{History}

We have witnessed extensive efforts of academics and institutions to prepare a draft for ECC to unify the civil law issues in Europe. About the necessity of such a code, Collins states that "Does Europe need a civil code? Does the European Union require an extensive system of principles of private law, including the laws governing obligations, property rights, and family obligations? In my view, it does need such a common framework of principles of private law." ${ }^{2}$ (Collins, 2007)

The ultimate aim of the efforts for an ECC is to introduce a common code in all the European countries, covering the main areas of law, which are traditionally dealt with national civil codes, namely law of persons, family law, inheritance law, property law and the law of obligations. The law of obligations includes the law of contracts, torts and unjust enrichment.

The most recent comprehensive civil code enacted in Europe is the Dutch Burgerlijk Wetboek which came into force in 1992. It covers all the related areas of civil law, including commercial law, consumer law and labour law. It took almost forty years to prepare this code. It is not difficult to assume that the time needed to make an ECC would not be less.

\footnotetext{
${ }^{2}$ He believes that the ECC will contribute to the integrity of Europe. "For those like myself who want to achieve a closer union of principles of Europe and who feel frustrated at the ineffectiveness and inefficiencies of the current political arrangements in Europe, the vital step to take, it will be argued, is not to revive talk of a political constitution, but rather to build from the ground upwards through common principles of private law expressed in a European civil code (Collins, 2007).
} 
The idea of a unified ECC goes back to the foundation of the European Union. First real action towards a unified ECC was the formation of the Commission on European Contract Law, which was led by Ole Lando. The Lando Commission worked the Principles of European Contract Law (PECL). The first part of the PECL was published in 1995 and then Part II in 1999 and the final Part III in 2003. It was expected that these would form one part of the European civil code.

In 1997 a conference on 'Towards a European Civil Code' was held, which considered the feasibility of such an ECC, and conference papers were published in 'Towards a European Civil Code'. ${ }^{3}$ The fourth edition of the book was published in 2010. The book consists of chapters covering all the issues and institutions of civil law.

Communication from the Commission to the Council and the European Parliament on European Contract Law (11.07.2001 COM (2001) 398 final) summarizes the journey of EU civil code then. The next paragraph presents the chronological process of the efforts for the unification of the EU civil law, which is a summary from various EU official documents and the Communication mentioned above.

The European Parliament requested the creation of an ECC in 1989, 1994 and 2000. The European Parliament adopted a number of resolutions on the possible harmonisation of substantive private law. In 1989 (Resolution A2-157/89, OJ EC 1989, C 158/400) and 1994 (OJ C 205, 25.7.1994: 518 (Resolution A3-0329/94) the European Parliament called for work to be started on the possibility of drawing up a common European Code of Private Law. The Parliament stated that harmonisation of certain sectors of private law was essential to the completion of the internal market. The Parliament further stated that unification of major branches of private law in the form of an ECC would be the most effective way of carrying out harmonisation with a view to meeting the Community's legal requirements in order to achieve a single market without frontiers. Furthermore, in its resolution of 16 March 2000 concerning the Commission`s work program 2000 (OJ C 377, 29.12.2000: 323 (Resolution B5-0228, 0229 - 0230 / 2000), the European Parliament stated "that greater harmonisation of civil law has become essential in the internal market" and called on the Commission to draw up a study in this area. In its reply of 25 July 2000 to the European Parliament, the Commission stated that it would "present a communication to the other Community institutions and the general public with the aim of launching a detailed and wide-ranging discussion, without losing sight of the date of 2001 set by the European Council" at

${ }^{3}$ It is Ed. By Arthur Hartkamp Towards a the Study Group on the European Civil Code (Fourth Edition) (Wolter Kluver, 2010) 
Tampere. The communication would "analyse this legislation - in force or in preparation - at Community level in the relevant areas of civil law in order to identify and assess any gaps, as well as the academic work which has been or is being carried out" $(\operatorname{COM}(2001) 398$ final) This Communication (Green Paper) presents four options for the EU contract law initiatives: Option I: No EC action Option II: Promote the development of common contract law principles leading to more convergence of national laws Option III: Improve the quality of legislation already in place Option IV: Adopt new comprehensive legislation at EC level. (COM (2001) 398 final:14-18)

Later, the Commission released an Action Plan for a more coherent European contract law in 2003. (Commission Communication, A More Coherent European Contract Law - An Action Plan (2003/C 63/01))

This action plan suggests a mix of non-regulatory and regulatory measures in order to solve those problems. "In addition to appropriate sector-specific interventions, this includes measures: - to increase the coherence of the Community acquis in the area of contract law, - to promote the elaboration of EU-wide general contract terms, and - to examine further whether problems in the European contract law area may require non-sector specific solutions such as an optional instrument." (Information in this paragraph has been summarized from Action Plan $(2003 / \mathrm{C} 63 / 01)$

Hesselink explains the functions of this action plan as:

The action planned by the Commission was threefold: 1) to encourage the development by European businesses of Europe-wide standard terms by opening a web site where they could publish their best practices; 2) to revise the acquis; and 3) to think further about a European code (eg an optional contracts code, opt-in or opt-out). With a view to the latter two actions the Commission announced that it would fund academic research which should lead to the compilation of a 'common frame of reference' (CFR). (Hesselink, 2004:686)

This was followed by the publication of "European Contract Law and revision of the acquis: the way forward" in 2004. (COM (2004) 651 final)

The Commission will establish specific opportunities for exchange of information on the opportuneness of such an instrument. Although it is premature to speculate about the possible outcome of the reflection, it is important to explain that it is neither the Commission's intention to propose a "European civil code" which would harmonise contract laws of Member States, nor should the reflections be seen as in any way calling into question the current approaches to promoting free circulation on the basis of flexible and efficient solutions. (COM (2004) 651 final:8) 
According to this Communication, The Action Plan identified different categories of problems of the acquis. The main ones were:

1. Use of abstract legal terms in directives which are either not defined or too broadly defined 2. Areas where the application of directives does not solve the problems in practice 3. Differences between national implementing laws deriving from the use of minimum harmonisation in consumer protection directives 4 . Inconsistencies in EC contract law legislation."(COM (2004) 651 final)

It also defines the main role for CFR:

If so, the Commission will use the CFR as a toolbox, where appropriate, when presenting proposals to improve the quality and coherence of the existing acquis and future legal instruments in the area of contract law. At the same time, it will serve the purpose of simplifying the acquis. ${ }^{4}$ The CFR will provide clear definitions of legal terms, fundamental principles and coherent model rules of contract law, drawing on the EC acquis and on best solutions found in Member States' legal orders. (COM (2004) 651 final: 4).

The next step was Green Paper from the Commission on Policy Options for Progress Towards a European Contract Law for Consumers and Businesses Brussels, 1.7.2010 COM (2010) 348 final.

The purpose of this Green Paper is to set out the options on how to strengthen the internal market by making progress in the area of European Contract Law, and launch a public consultation on them. Depending on the evaluation of the results of the consultation, the Commission could propose further action by 2012. Any legislative proposal will be accompanied by an appropriate impact assessment. (COM (2010) 348 final:2) The Green Paper presents seven options: "Option 1: Publication of the results of the Expert Group, Option 2: An official "toolbox" for the legislator, Option 3: Commission Recommendation on European Contract Law, Option 4: Regulation setting up an optional instrument of European Contract Law, Option 5: Directive on European Contract Law, Option 6: Regulation establishing a European Contract Law, Option 7: Regulation establishing a European Civil Code.

Meantime, an Interim Outline Edition of the Draft Common Frame of Reference (DCFR) for European private law was published in February 2008, and the definitive Outline Edition was published in February 2009. ${ }^{5}$ By the end

4 This initiative is included in the scope of the Commission Communication on "Updating and simplifying the Community acquis" $(\mathrm{COM}(2003) 71)$ and aims at achieving legislative simplification.

${ }^{5}$ Von Bar, C. Principles, Definitions and Model Rules of European Private Law: Draft Common Frame of Reference (DCFR) (Sellier European Law Publishers, 2009) 
of 2009, the full work (i.e. model rules, comments and comparative notes) was published in paper, consisting of six volumes comprising about 6,100 pages. The DCFR project was launched and sponsored by the Commission of the European Union. Jansen and Zimmerman sarcastically criticizes the term of CFR and DCFR's role by saying:

[...] ever since the enigmatic term "Common Frame of Reference" (CFR) was coined in a Communication from 2003, commentators have been trying to figure out what it might be intended to mean. The Commission itself has repeatedly stated that the CFR is supposed to be a "tool box" for future legislation in the field of contract law. But the CFR might also conceivably serve as an optional instrument. (Jansen and Zimmermann, 2010: 98)

The introduction of the Proposal for a Regulation on Common European Sales Law (CESL) was described as the "biggest step" by the Commission. (COM 635 final 2011/0284) The purpose of this Regulation was announced as improving the "conditions for the establishment and the functioning of the internal market by making available a uniform set of contract law rules as set out in Annex I (the Common European Sales Law)." (COM 635 final 2011/0284)

However, The EU Commission's Work Programme for 2015 listed CESL in the Annex of withdrawn proposals. It was stated that this draft Regulation was withdrawn "in order to fully unleash the potential of e-commerce in the Digital Single Market." (Commission Work Programme 2015)

The Digital Single Market Strategy adopted by the Commission on 6 May 2015 announced a legislative initiative on harmonised rules for the supply of digital content and online sales of goods. This initiative is composed of (i) a proposal on certain aspects concerning contracts for the supply of digital content, and (ii) a proposal on certain aspects concerning contracts for the online and other distance sales of goods. Finally, Proposal for A Directive of the European Parliament and of the Council on certain aspects concerning contracts for the supply of digital content COM (2015) 634 final 2015/0287 (COD) was released.

According to the Commission, this is the "last EU document related to the EU Civil law". (COM (2015) 192 final) Therefore, this is where the formal chronology for the EU ends.

\section{Competence of the EU to Regulate an ECC}

Article $288^{6}$ of the Treaty on the Functioning of the European Union (TFEU) empowers the European Union institutions to introduce legislative acts

6 "To exercise the Union's competences, the institutions shall adopt regulations, directives, decisions, recommendations and opinions. A regulation shall have general application. It 
at the EU level. It is known that to bind the Member States to a unified civil law through a legislative act, the principle of conferral of competences as articulated in Art. 5 of the Treaty on European Union (TEU) needs to be observed. This principle stipulates that no competence can be used by the EU that is not conferred upon it by the EU treaties. (The TEU and the TFEU) Such a corresponding competence might be found in Articles 114 or 115 of the TFEU or Art. 352 of the TFEU.

The Articles 114 and 115 are both related to Internal Market, which is placed under 'shared competence' category by Art. 4 of the TFEU. It means that the area can be both regulated by the EU and the Member States, though in accordance with the so-called 'pre-emption' principle stipulated in Art. 2 (2) of the TFEU, which prescribes that the Member States can exercise their competence only to the extent that the Union has not exercised, or has decided to cease to exercise its competence. This poses two problems in terms of an ECC. The first one is the potential outcome that involves further national regulation of areas, which may be left out by an ECC. The design of shared competence, due to pre-emption, has the inherited possibility that may still lead to national divergences among Member States. This potential consequence may undermine the whole purpose of the ECC idea. A second problem lies with the application of the 'subsidiarity principle'. Any legislative act based on shared competence is subject to 'subsidiarity principle', which sets forth that: "in areas which do not fall within its exclusive competence, the Union shall act only if and insofar as the objectives of the proposed action cannot be sufficiently achieved by the Member States, either at central level or at regional and local level, but can rather, by reason of the scale or effects of the proposed action, be better achieved at Union level." (Art. 5 (3) TEU). This principle governs the use of competence by the EU, ensuring that "excessive use of power" and "excessive centralization" is avoided. (Craig, 2012) The process of subsidiarity control of the EU competence, inter alia, involves the requirement to prove the necessity of an EU-wide action. This may be a challenging job, considering that the level of 'necessity' may prove insufficient to fulfil subsidiarity principle; since it is a matter of 'desirability', rather than a 'necessity', where a comprehensive ECC is the subject.

In terms of a substantive examination of the subject of competence for an ECC, Art. 114 of the TFEU together with Art. 26 of the TFEU, offers a competence for actions to establish and administer the Internal Market.

shall be binding in its entirety and directly applicable in all Member States. A directive shall be binding, as to the result to be achieved, upon each Member State to which it is addressed, but shall leave to the national authorities the choice of form and methods. A decision shall be binding in its entirety. A decision which specifies those to whom it is addressed shall be binding only on them. Recommendations and opinions shall have no binding force." 
(Schmid, 2012) Article $114 / 1^{7}$ of the TFEU provides provisions for the achievement of the objectives set out in Art. 26. ${ }^{8}$ Therefore, any legislative activity based on Art. 114 should represent an effort to 'eliminate barriers to trade' following the 'Internal Market' purpose of the Article. In other words, approximation of laws should remedy the barriers to trade caused by divergent national laws of the Member States. So any attempt to codify an ECC should initially prove that the divergent national civil laws create a barrier to intraUnion trade, with reference to the 'necessity' requirement of the subsidiarity principle.

Moreover, functioning of the Internal Market revolves around free movement, which requires, inter alia, the involvement of a cross-border element. The cross-borderness in respect of an ECC may only be conceivable with cross-border contracts. The use of Art. 114 as a legal ground for a possible EU legislative act towards the creation of an ECC would likely to be next to impossible to justify for any area of civil law outside the cross-border contracts. Only in specific areas, where problems in cross-border trade occur, the European Union has the power to do so. (Rutgers, 2010:12) For that reason, this article does not seem to provide a sufficient/appropriate legal ground of competence for the EU civil code. The same explanations are also notable for the employment of Art.115 as a legal ground. ${ }^{9}$

This conclusion leads us to explore further possibilities. An alternative ground of competence may be found at the Art. 352 of the TFEU, which empowers the Union to take necessary action to achieve the treaty objectives; in our case, the 'EU civil code'. Article 352/1 stipulates that:

7 "The European Parliament and the Council shall, acting in accordance with the ordinary legislative procedure and after consulting the Economic and Social Committee, adopt the measures for the approximation of the provisions laid down by law, regulation or administrative action in Member States which have as their object the establishment and functioning of the internal market."

8 " 1 . The Union shall adopt measures with the aim of establishing or ensuring the functioning of the internal market, in accordance with the relevant provisions of the Treaties.

2. The internal market shall comprise an area without internal frontiers in which the free movement of goods, persons, services and capital is ensured in accordance with the provisions of the Treaties.

3. The Council, on a proposal from the Commission, shall determine the guidelines and conditions necessary to ensure balanced progress in all the sectors concerned."

9 "Without prejudice to Article 114, the Council shall, acting unanimously in accordance with a special legislative procedure and after consulting the European Parliament and the Economic and Social Committee, issue directives for the approximation of such laws, regulations or administrative provisions of the Member States as directly affect the establishment or functioning of the internal market." 
1. If action by the Union should prove necessary, within the framework of the policies defined in the Treaties, to attain one of the objectives set out in the Treaties, and the Treaties have not provided the necessary powers, the Council, acting unanimously on a proposal from the Commission and after obtaining the consent of the European Parliament, shall adopt the appropriate measures. Where the measures in question are adopted by the Council in accordance with a special legislative procedure, it shall also act unanimously on a proposal from the Commission and after obtaining the consent of the European Parliament. ${ }^{10}$

Here it is difficult to find out what kind of 'Treaty objective' may justify such an action based on Art. 352 competences. The objective of "creating an ever closer union among the peoples of Europe" as set out in the Art.1 of the TEU? Absolutely not, if one continues to read the provision, which provides that: "in which decisions are taken as openly as possible and as closely as possible to the citizen." 11 Here creation of an ECC appears to contradict the subsidiarity objective pursued by the EU. It also goes against 'pluralism' as referred by Art. 2 of the TEU. Article 3 (3) of the TEU mentions that the Union shall respect to 'cultural diversity' and ensure 'cultural heritage is safeguarded'. This could probably be interpreted to include legal cultures of the Member States. Yet, the ECC project would also endanger the cultural legal heritages. One possibility may be the "strict observance and the development of international law" aim as stipulated by Art. 3 (5) of the TEU, considering the unification efforts and examples of international private law, in particular in law of contracts. ${ }^{12}$ However, this is a remote basis that is unlikely to be able to initiate a legislative process based on Art. 352 of the TFEU. Therefore, Art. 352 is also not likely to serve as a legal ground for a possible ECC instrument by the EU.

Collins comments that: "If a general consensus were to be reached in favour of a European civil code, it might be politically possible to expand the constitutional competence of the European Union or create an international treaty giving effect to the code." (Collins, 2007) Considering the general resistance of the Member States to transfer more portions of their sovereignty to the EU, the general expansion of constitutional competence of the EU may be unlikely. Enhanced co-operation may be an answer, but the scheme, being optional, would be incompatible with the unification concern of the ECC. However, it is always a possibility to design an ECC instrument in the form of an international treaty by the Member States, where the competence problem

\footnotetext{
${ }^{10}$ Emphasis added by the authors.

${ }^{11}$ Emphasis added by the authors.

${ }^{12}$ For instance: The United Nations Convention on Contracts for the International Sale of Goods (CISG) and the UNIDROIT Principles of International Commercial Contracts
} 
within the EU cannot be resolved. Yet, any unification measure by the Member States, which is leaving the EU out, could be a political loss on behalf of the EU.

\section{Arguments For and Against an ECC}

\section{The Internal Market}

The Internal Market, which lies at the heart of most EU policy making is currently under strain. As Monti puts it: "The single market today is less popular than ever, while Europe needs it more than ever." (Monti, 2010:6) The main arguments in favour of an ECC centres on the idea of ensuring a wellorganised and well-functioning Internal Market, which increases the attractiveness of the argument under the unfavourable circumstances surrounding the Internal Market. For instance Lando explains that:

[...]These differences complicate foreign trade. At least one party to an international contract has to be subject to an alien legal system and will often have to invest a great deal of time, effort and money to become familiar with the foreign law. Venturing into a foreign market is risky, and many companies, especially small and medium-sized businesses, are wary of doing so. The legal differences are therefore obstacles to the free movement of goods, people and services, obstacles which are fundamentally irreconcilable with the principle of a common market. (Lando, 1999:127)

Lapuente also lists three basic arguments, which the supporters of the harmonisation base their ideas, and states the first one as:

On the need to achieve the ends of the internal market, particularly since many examples show that the differences between the national rules in the field of the Contract Law are a real obstacle to the free movement of goods as they reduce the eagerness to make cross-border deals, involve huge transaction costs to investigate the legal system of the other contracting party and do not allow to implement a uniform sales strategy." (Lapuente, 2002:89)

It is evident that, where there is an Internal Market efficiency concern, cross-national feature of a subject becomes prominent, and this transfrontier aspect calls-for legislation at the Union level. (Tekin Apaydin, 2014:11) However, such arguments adopt a perspective that reduces civil law to the law of obligations. Currently, it is not easy to extent these arguments to all civil law matters, which cover various areas of private law. Harmonising the Internal Market might be one of the reasons to codify the civil law in the EU, but it cannot be presented as the sole intention. Therefore, the Internal Market argument would constitute one in favour of an ECC, albeit limited. 


\section{Conflict of Laws}

One can say that the EU does not need to unify civil law as it has solved the civil law related disputes by regulating the private international law, i.e. conflict of laws. (Kunda \& Marinho, 2010) As a response to this assert, it can be said that it has meandered for more than 200 years and could easily mislead the legal layperson to the following judgment: "private international law is the cause of a problem, for which it regards itself as solution." (Schmidtchen, 2002:473) Moreover, as often criticised,

[...]at least one party to an international contract has to be subject to an alien legal system and will often have to invest a great deal of time, effort and money to become familiar with the foreign law. Venturing into a foreign market is risky, and many companies, especially small and medium-sized businesses, are wary of doing so. The legal differences are therefore obstacles to the free movement of goods, people and services, obstacles which are fundamentally irreconcilable with the principle of a common market. (Lando, 1999:127)

Doubtlessly, a unified civil code in the EU would dismiss such concerns arisen by the application of the conflict of laws.

\section{Common Law v Civil Law}

There are two main legal families in the world: common law and civil law, which differ greatly especially relating to the legal areas covered by a civil code. Moreover, the notion of civil code is an unknown concept for the common lawyers and the common law countries. There are three common law countries (the UK, Ireland and Cyprus) and a mix legal system country (Malta) in the EU.

In this context, 'good faith' is one of the major obstacles for an EU civil code. The common law countries do not seem to consent to a unified law of obligation regulation for the EU, containing a general duty to act in good faith and fair dealing. Allegedly, that is why the UK has not joined the CISG. On the other hand, the civil law countries in Europe may seem to overcome their hesitations about trust, a mere and distinctive product of English law, with Draft Frame of Common Reference. (Apaydın, 2016:1789) About this discussion, Schmid concludes that:

Switching the entire legal system of a country is indeed very difficult. Every single lawyer, judge, professor, student and everyone else who is working with the law would have to learn a new way of thinking. All the precedents and legal traditions of those countries would be more or less useless. Furthermore, the public, all the people who are not confronted with the law in their everyday life but have a basic legal knowledge/understanding, would be doomed to relearn everything they 
know about the law. Not only would it take a long time until the new system would be accepted and function as well as the old one, it would also be very costly to re-train all the legal professionals and change the educational system for the future ones. (Schmid, 2002:277-278)

Nevertheless, the common law and civil law duality may appear as a challenge at first sight for an ECC, but on the positive, it can also serve as an enriching factor that cultivates the ECC with their contributions deriving from different backgrounds. It is possible that each system may have an answer for the problems encountered in the other.

\section{Nationalism}

One of the architects of the idea of EU civil code, Lando, states that:

The discussions on EU civil code took place when nationalism rises throughout the world. If affected the Member States too. For instance, any standardisation of substantive property law will meet with fierce resistance in the countries of the EU. This not only applies to England and Ireland, where the people, and particularly the lawyers, proudly cherish their common-law tradition, but also in France, where the Code Napoléon is regarded as a cornerstone of the nation's cultural heritage. (Lando, 1999:127)

As observed, especially French authors are fiercely against a new EU civil code, which would replace the national codes. Here is a rather humorous analogy by Michaels, who depicts how nationalism would affect the work for a unified EU civil code:

French academics reacted to announcements about a possible future European Civil Code ten years ago in the way in which Americans reacted to the Japanese attack on Pearl Harbor 1940: first with shock, then with rearmament, finally with attempted counterattacks. Military metaphors abound. Yet the defence of the French Code Civil against an European Civil Code is tricky: they must defend one Code against another. [...] Nonetheless, the point is not to dismiss these defences. Rather, they should be understood as expressions of faith-and the discussion over a European Code resembles, in part, a religious war [...] (Michaels, 2012:277)

Where a European Code threatens to replace the code civil with something different, it must be opposed. Where, by contrast, the code civil is allowed to become a European Code - whether directly, through adoption elsewhere, or indirectly, through stronger influence on European law-making, Europeanization is supported. (Michaels, 2012:293)

It is well possible to assert the same arguments for the Germans, Italians and Austrians. It appears that, they are quite happy with their civil codes and do not 
seem to show any eagerness to replace it with a new one. In response to this adverse argument, it is said by the intrepid defender of the EU civil code, Lando, that "while it is not a law of nature that political and economic unions gradually come to share the same civil law, experience has shown that it does often happen. This was seen in France, when the Code Civil and the Code de Commerce were introduced in 1804 and 1807 respectively, in Germany in 1900 and again in 1990; Austria (1812), Italy (1865) and the Swiss codifications of 1907-11 are further examples." (Lando, 1999:128)

\section{Culture}

To respect for cultural diversity and to safeguard and enhance cultural heritage of the Member States are quoted as one of the objectives of the EU in Art.3 of the TEU. On the other hand, the EU itself represents the unification of Europe and a reduction in the significance of national borders. This quandary is formulated in "United in Diversity" motto by the EU. The creation of an ECC can be seen as a further step to improve the integration process. Differences in national laws may create problems of efficacy in the ever more globalised economy. A uniform civil code will help overcome these problems and reduce barriers to increased trade within the European Union. (Collins, 2007)

Ideally, a civil code may only be applied to people, who have more or less the same cultural background, for it covers almost every aspect of a human being and so the people. A civil code, as we experience from the national civil laws, deals with law of persons, law of family, property law, inheritance law and law of obligations. In this context, it is not quite possible to conclude that there is a legal cultural structure, related to the civil code context, covering the whole Europe. As a compromise, it is suggested that family and inheritance law will remain with the Member States. This will leave intact the part of the law that is influenced most by culture and tradition and that also is of least importance for the completion of the Internal Market. (Schmid, 2002:279-281) This might work. As seen, many African and Middle Eastern countries adopted the French Civil Code as their civil code, leaving the family and inheritance law issues to Islamic law, Sharia.

Indeed, here, one may claim that there was ius commune on the law of obligations for the whole Europe, which was based on Roman law. However, this argument is not completely accurate as it neglects the common law countries. Secondly, even if it were correct, although the efforts towards the EU civil law focused on law of obligations continue for almost three decades, the EU could not manage to produce one single document unifying the law of obligations in the EU. Where the differences regarding civil law institutions such as capacity age, marriage age, marriage, inheritance, rights on land, so on 
and so forth are quite huge and versatile that, it does not seem easy to reach a consensus on these matters.

Let's leave aside law of persons, law of family and inheritance law issues, as the co-author of this paper (Eylem Apaydin) studied English property law at his doctorate, the origins of which go back to the $11^{\text {th }}$ century, it is a confident conclusion to express that English property law would not be regulated by a civil code based on Roman law, overlooking the rules evolved through one thousand years of the common law tradition. Nevertheless, Lando, in favour of the unification of civil law, comments bitterly:

The resistance of European lawyers to the standardisation of civil law is unavoidable. But it is there to be overcome. We know of the centuries of stubborn resistance to standardisation of the laws of France before the Revolution of 1789. Corrupt lawyers, the so-called noblesse de robe, were loath to learn new law and to give up their local monopolies. It is also questionable whether the new Bürgerliches Gesetzbuch was greeted enthusiastically throughout Germany in 1900. And is it now receiving acclaim in the five new Länder of the Federal Republic? Allowance has to be made for scepticism and resistance. (Lando, 1999:128)

Lapuente in his article about the ECC lists the main arguments against a standardised Law of Obligations, which include, among others: "(a) the lack of common concepts and techniques applicable to legal problems as a consequence of the centenarian isolated traditions; (b) the diversity of the legal and cultural mindsets, particularly evident in the case of the Civil Law and the Common Law" (Lapuente, 2002:89) ${ }^{13}$ As seen, his arguments centre on the cultural differences as well.

To sum up, the cultural differences among the European countries embody an actual hindrance for a unified civil code in Europe. However, some still believe that it would be overcome. Some authors even perceive these differences as a positive influence. For instance, Schmid, with a rather romantic argument, emphasises the importance of the ECC for a truly unified Europe and the positive influence it may have on improving solidary among the Member States:

First and foremost, the enactment of a European Civil Code would be a tremendous signal to the rest of the world, showing European strength, unity and togetherness. This would help to enlarge the importance of the European Union in the world and make the EU a more competitive player on the global market. It would moreover be a symbol for the

${ }^{13}$ He continues the arguments "(c) the need to respect the pluralism, claiming that the basis of the cultural concept of Europe relies on the diversity itself (in social, linguistic, cultural and legal terms). (d) the insufficient number of cross-border transactions; and (e) the loss of the advantages that a "competition between legal orders" might imply." 
European Union and solidarity among the Member States as stipulated by Art. 4 TEU. A European Civil Code could even help to create a European identity." (Schmid, 2002:274)

As seen, these are hopes and assumptions, but not factual predictions. In reality, on one end, there would be an ECC prescribing one thing on a subject; while on the other end of the spectrum, there could be different cultural legal backgrounds which would potentially dictate otherwise.

\section{Language}

The EU currently has 24 official languages. Any EU document should be written in these twenty four languages. This number could increase if any further enlargement takes place. Even though the CISG was drafted and adopted in the six official languages of the United Nations - Arabic, Chinese, English, French, Russian, and Spanish, it appears that there are some disputes over the text originated from the translations and interpretations. (Germain, 2016) When taking into account 24 translated versions of an EU civil code, it is well likely to have disputes over the civil code text itself, which would affect the unified application of the code severely. Each Member State would probably tend to interpret the same text in accordance with their own traditional legal background.

At that point Schmid proposed that English could be the common language of the EU by establishing it as the official language for business and science. "Implementing a European Civil Code requires the implementation of English as a common European language of science and business. This is a very ambitious goal, but at the same time an enormous opportunity to strengthen the position of the European Union on the global market, support the internal market and create a European identity." (Schmid, 2002:277) It is only ironic that, Schmid could not predict the future. The UK, as the only Member State, the official language of which is English, is in the process of initiating the leave talks with the EU upon the 'Brexit' decision of the British people. Moreover, the European Union's lead Brexit negotiator, Michael Bernier, wants British and EU officials to work in French rather than English during the divorce talks. (Independent, 2016) Hence the proposal for English being a common language for an ECC does not seem likely anymore.

\section{Cost}

There are two concerns about the cost regarding the European Civil Code. Firstly, as the Commission also assumes, it is quite apparent that transaction costs within the Internal Market would be likely to diminish if there were a unified ECC. (COM (2010) 348 final) On the other hand, seemingly, to draw up and implement the EU civil code would bring along significant costs for the EU. Firstly, the making process of the code could take up to forty years, maybe 
more, as did the Dutch Burgerlijk Wetboek and the EU would need to provide finances for these preparation work. Secondly, to provide the unified application of a civil code, it is necessary to construct an appeal court in Europe, which also would cost a good sum of money. Moreover, the legal practitioners and maybe the scholars would require support in their learning and adaptation process. Such vocational courses could be extended to include relevant public and private bodies. Although this may not necessarily be an EUfunded item, it is likely that the EU would spare funds for such activities. In either case, it would be a cost to be burdened, as a direct consequence of introducing a unified ECC.

\section{Legal Instruments Available in EU law to Regulate an ECC}

\section{Possibilities}

Assuming that the EU has competence to regulate the area, an ECC may be drafted by one of these four methodological approaches, as Lapuente clearly and precisely demonstrates:

a. To take one or several national Civil Codes as models or to take the most representative codes of each legal tradition and the corpus of rules of the Common Law.

b. To try to produce a compilation of rules covering real common principles or to create new rules that do not exist, on their own, in any European legal system.

c. The third methodological approach advocates using previous legal concepts, which can have different levels of intelligibility in a number of legal systems, or a system of practical cases where each national reporter can try to provide the solutions on the basis of the national legal categories.

d. The fourth methodological approach involves focusing on the comparative efforts of the existing laws in the different continental systems, or giving a largely relevant role to the "legal formants". (Lapuente, 2002:94)

As observed, the efforts for a unified civil code for Europe focus on the comparative studies, which compare the civil codes in force in Europe and common law and try to compromise these two completely different legal systems. Hence, it can be noted that the current approach, which is adapted, corresponds to approach ' $A$ ' according to the Lapuente's classification. Some can say that this approach may work as it happens in drafting the CISG, even though the fact that the UK refuses to join it. After Brexit, there is a possibility that the impact of common law may become less of a concern while drafting the EU civil code, with the reduced influence of common law. However, one should admit that although this may seem a viable way to codify a code, it would still be a challenge to converge the main civil codes in Europe, such as 
French Civil Code, German Civil Code, Swiss Civil Code, Portuguese Civil Code, Spanish Civil Code, Italian Civil Code, Netherlands Civil Code, Austria Civil Code, which have many different, sometimes conflicting regulations on civil matters.

Principles of European Contract Law (PECL) preferred to employ the approach 'B'. However, in a short time, it was witnessed that this approach would not work, as it was never embraced, and therefore their adoption has never been officially suggested.

Apart from these approaches, there are five possibilities in current EU law on how a drafted EU civil code may be put in use. Next, we will explore these possibilities and discuss their appropriateness.

\section{Model law}

The text on the possible ECC could be used as a "Model Law" like the PECL. As a result of this form, an EU country may enact this model law in any form of legal instruments; as an act or lower degree regulations. Even, some countries may prefer to stand idly by it. Apparently, this is not a favourable solution especially for the defenders of the ECC, since it does not impose the compulsory application of the code. In such a method, the Member States would have the option to opt-in to or to opt-out from the scheme. By design, it is a threat to unification. "Its acceptance would depend on the level of uniformisation and on the time expected for it to overcome the obstacles to the internal market. Perhaps a Recommendation might be useful for it." (Lapuente, 2002: 98)

\section{Recommendations and Opinions}

"A "recommendation" is not binding. [...] A recommendation allows the institutions to make their views known and to suggest a line of action without imposing any legal obligation on those to whom it is addressed." (europa.eu website, definitions)

"An "opinion" is an instrument that allows the institutions to make a statement in a non-binding fashion, in other words without imposing any legal obligation on those to whom it is addressed. An opinion is not binding. It can be issued by the main EU institutions (Commission, Council, Parliament), the Committee of the Regions and the European Economic and Social Committee. While laws are being made, the committees give opinions from their specific regional or economic and social viewpoint." (europa.eu website, definitions)

Article 288 of the TFEU articulates that both the Recommendations and Opinions have no binding power. In effect, they are no different from model law. They are all forms of soft law that cannot be legally enforced. Hence, it is apparent that a unified EU civil law and an EU civil code cannot be achieved 
through Recommendations and Opinions, because they do not have a binding character.

\section{Decisions}

"A "decision" is binding on those to whom it is addressed (e.g. an EU country or an individual company) and is directly applicable. For example, the Commission issued a decision on the EU participating in the work of various counter-terrorism organisations. The decision related to these organisations only." (europa.eu website, definitions)

According to the definition provided by the Art. 288 of the TFEU, a Decision has two important characteristics: -binding in its entirety, and -binding only for the addressees. In contrast with the Recommendations and Opinions, Decisions do not have any issues with the binding force they have. Though, they bear the force they require for an ECC. 'Binding in its entirety' formula refers to the fact that whatever is written in the text, whichever wording was used will be the actual binding text for the Member States. This also represents a characteristic that is fit for our purpose. However, the decisions are rather designed for communicating binding, yet 'custom-made rules' to those specified, whether it be a Member State, a company or an individual. Therefore, they are often used in areas such as competition and state aid. (Craig and de Búrca, 2011:107) So they are not likely to be the best option to design an allencompassing legislative act to unify the EU civil law.

\section{Directive}

A "directive" is a legislative act that sets out a goal that all EU countries must achieve. However, it is up to the individual countries to devise their own laws on how to reach these goals. One example is the EU consumer rights directive, which strengthens rights for consumers across the EU, for example by eliminating hidden charges and costs on the internet, and extending the period under which consumers can withdraw from a sales contract. (europa.eu website, definitions)

According to the definition of the Art. 288 of the TFEU, a Directive as a legal act, ${ }^{14}$ has two main characteristics: - binding as to the result to be achieved, leaving the choice of forms and methods to the Member States, and binding upon each Member State indicated as addressees.

The first one is related to what is commonly referred as the 'direct applicability' principle; or more accurately the absence thereof. The design of

\footnotetext{
${ }^{14}$ After the entry into force of the Lisbon Treaty, there are three different types of secondary norms enacted by the EU institutions: the legislative acts (ART.289 TFEU), the delegated acts (Art.290 TFEU), and the implementing acts (Art. 291 TFEU). All three types may be enacted in the forms of regulation, directive or decision. For the purpose of this paper, all such EU law instruments will be taken to refer to 'legislative acts'.
} 
the Directives requires transposition into national law, meaning that they are not directly applicable. The prescribed 'objectives' demand implementation into the domestic law by a national measure. The form and method employed for implementation is irrelevant for the EU. It is rather a result-oriented obligation. The binding part here relates to the attainment of the objectives set out by the Directive. The Directive presents a framework and sets out the goals. It is the duty of the Member States to implement national measures to comply with those requirements within the prescribed time-limit. That is why, any implementation by Member States of a Directive's content requires some time, which is usually between 12 to 36 months. Furthermore, to implement a Directive correctly, Member States must ensure that national legislation complies with it fully and within the designated time limit. (Grant, Matthews and Newell, 2000:71) Still, this flexibility inherited in the Directive makes it the most preferred instrument as a legislative act, for its respect for national sovereignty. It is particularly efficient as a tool for the approximation of national laws. (Craig and de Búrca, 2011:106) However, it is evident that Directives usually lead to discrepancies between the laws of the Member States, particularly where minimum harmonisation approach is adopted. ${ }^{15}$ Even where maximum harmonisation approach, which is closer to unification, is adopted, this may still be a problem as there is scope for potentially harbouring any national differences deriving from the variations in the 'transposition process'. This is a hampering weakness for an ECC, which aims at unification. These weaknesses were also pointed out by Schmid:

[...] directives oftentimes are not very precise concerning their goal, thereby leaving the national governments a lot of possibilities for the realization process. However, combined with the freedom of choice, form and method, it can also lead to different outcomes in each Member State. Therefore, directives are unsuitable to reach the goal of unification." (Schmid, 2012:268)

Nonetheless, as expected, he does not neglect to identify a possible advantage of regulating an ECC through a Directive:

[...] by leaving the choice of form and method to the Member States, directives bear the advantage that the national governments can put the new European law into the right context of the already existing body of national law. This helps to avoid inconsistencies. (Schmid, 2012:267)

\footnotetext{
15 Minimum harmonisation sets minimum standards, which enables Member States to introduce more stringent rules than those prescribed by the Directive. On the other hand, maximum harmonisation regulates the whole area and leaves no scope for further national legislation in the defined field. Therefore, the use of maximum harmonisation in areas such as consumer protection, becomes a subject of debate, as it deprives the Member States of their rights to introduce more protective measures.
} 
This appears to be a minor one compared to the above-given disadvantages.

The second feature underline two matters. First a Directive is an instrument that can only be addressed to Member States. Secondly a Directive does not necessarily needs to be addresses to the whole Member States. It can be directed to one or some of the Member States too. This second set of features do not pose any barriers or create advantages as to the use of a Directive as an instrument to enact an ECC, since it is possible -and even more common- to direct it to all Member States at once.

All in all, the use of a Directive as an instrument to unify the EU civil law is possible, then again not ideal. A Directive, by nature, contains in itself some distinct features, which may severely impair the unification aim of a common European civil law.

\section{Regulation}

A "regulation" is a binding legislative act. It must be applied in its entirety across the EU. For example, when the EU wanted to make sure that there are common safeguards on goods imported from outside the $\mathrm{EU}$, the Council adopted a regulation. (europa.eu website, definitions)

According to the definition of the Art. 288 of the TFEU, a regulation as a legal act, bears three main features. First, it has general application. Unlike Decisions and Directives, they cannot be addressed to certain addressees. They are legal instruments designed to have an abstract character and general application just like the national laws.

Secondly, a Regulation is binding in its entirety, just like the Decisions. Unlike Directives, what is binding is whatever is written in the text of the Regulation itself. There is no scope for national variations, which is desirable for unification.

Thirdly, it is directly applicable in all Member States. As explained above, unlike Directives, the Regulations do not require any implementation procedures to become applicable in the domestic legal systems of the Member States. Once it is published in the Official Journal of the EU, it enters into force on the date shown by the Regulation, or in the absence thereof, on the $20^{\text {th }}$ day following that of its publication. (Art. 297 of the TFEU) Thus, the Regulations become part of the national legal systems, without the need for transformation or adoption by separate national measures. (Craig and de Búrca, 2011:105) This is the key to unification. A Regulation becomes the law in all Member States, at the same time, having the same content. As Member States do not have any power to put their stamp on the legislative act, the only divergences possible may be those that emerge from translation-related variations, which is inevitable. 
An instrument in possession of all the peculiarities necessary to achieve unification in the field of civil law in the EU, would doubtlessly be Regulation. It is the most potent form of legislative acts available in EU law. An ECC, which would be legislated as an EU Regulation, would directly be in force as a uniform text, in all Member States, on the prescribed date, without the need for further national steps for implementation. The binding force of the Regulations is complemented and further fostered by 'supremacy of EU law' doctrine, ${ }^{16}$ which bestows upon the Regulation the power to render any conflicting national law of any type 'inapplicable', whether it be a former or a later one. This in effect means that even where Member States choose to preserve their own national civil codes, they could only be applicable so far as they overlap with the ECC.

Assume that only a part of civil law issues, such as contract law, has been enacted in the EU as a Regulation, then, the national civil codes would be in force to regulate the other matters at the same time with the EU contract law Regulation. This will inevitably cause conflicting law issues. Therefore, a unified complete civil law would be preferable to avoid confusion. However, it is not foreseen that a complete and comprehensive EU civil code that covers all the civil law issues would easily be accepted in the EU soon. As Hesselink says "Clearly, a comprehensive Code on all matters of private law which would replace all national private law would be the maximum. It is also the most unlikely outcome (at least in the foreseeable future)." (Hesselink, 2004:15-18)

As a result, a unified civil law, acting as an EU Civil Code may only be achieved through a Regulation. The latest example on the unification of sale law in the EU, the proposal of CESL, demonstrates that Member States also agree that Regulation is deemed to be the best instrument to unify law in the EU.

\section{Legal Texts}

\section{The Principles of European Contract Law}

The Principles of European Contract Law was prepared by the Commission for the European Contract Law known as the Lando Commission, consisted of

16 This doctrine was first established by the ECJ in the Costa v ENEL case of 1964, and reiterated later in various case-law. The founding argument presented in this case was the permanent transfer of some sovereign rights by the Member States to the Community. This argument was supported with various justifications, inter alia, the provision defining regulations as 'shall be binding' and 'directly applicable in all Member States'. It was submitted that this provision is subject to no reservation, and it would be quite meaningless if a Member State could unilaterally nullify its effect by a national legislative measure that could prevail Community law. All the references emphasised the supranational character of the then EEC. 
twenty three distinguished lawyers, which were assigned to codify the private law in the EU. (Lando, 1977) ${ }^{17}$ These Principles have never had an enforcement power in the EU and will never have. The Principles were drafted as a model law and functioned as an optional instrument in EU law. Application of the Principles is explained in Article 1.101 of the Principles;

(1) These Principles are intended to be applied as general rules of contract law in the European Communities. (2) These Principles will apply when the parties have agreed to incorporate them into their contract or that their contract is to be governed by them. (3) These Principles may be applied when the parties: (a) have agreed that their contract is to be governed by "general principles of law", the "lex mercatoria" or the like; or (b) have not chosen any system or rules of law to govern their contract. (4) These Principles may provide a solution to the issue raised where the system or rules of law applicable do not do so.

Hence, these principles were accepted as soft law or model law. The Content of the Principles of European Contract Law - Parts I and II Revised 1998 as: (Parts I And II Revised 1998, Part III 2002)

Chapter 1 - General Provisions

Chapter 2 - Formation

Chapter 3 - Authority of Agents

Chapter 4 - Validity

Chapter 5 - Interpretation

Chapter 6 - Contents and Effects

Chapter 7 - Performance

Chapter 8 - Non-Performance and Remedies in General

Chapter 9 - Particular Remedies for Non-Performance

Chapter 10: Plurality of Parties

Chapter 11. Assignment of Claims

Chapter 12. Substitution of New Debtor: Transfer of Contract

Chapter 13. Set-Off

Chapter 14. Prescription

Chapter 15. Illegality

Chapter 16. Conditions

Chapter 17. Capitalisation of Interest

17 http://www.jus.uio.no/lm/eu.principles.lando.commission/doc.html Lando, O., \& Beale, H, (Eds), Principles of European Contract Law, Parts I And II (2000); Lando, O., Clive, E., Prüm, A, \& Zimmermann, R., (eds), Principles of European Contract Law, Part III, (2003) Lando tells how this Commission works in his article (Lando,1977) 
As seen the Principles only cover the typical contract law matters. Thus, it cannot be regarded as the EU civil code but it may only be regarded as a part of it. $^{18}$

\section{The Draft Common Frame of Reference}

In 2001, with a communication, (COM (2001) 398 Final) ${ }^{19}$ the EU revealed its desire for the harmonisation of contract law. In this communication, some solutions were proposed and the last solution was "to adopt a new instrument at Community level, combining rules on general aspects of contract law and on specific questions". This purely represents the intention for the unification of the contract law in the EU with a binding legislation.

The first time we hear the "Common Frame of Reference" (CFR) was in a Communication from 2003. (COM/2003/0068 final) According to this communication:

[...] this common frame of reference should provide for best solutions in terms of common terminology and rules [...] A review of the current European contract law acquis could remedy identified inconsistencies, increase the quality of drafting, simplify and clarify existing provisions, adapt existing legislation to economic and commercial developments which were not foreseen at the time of adoption and fill gaps in EC legislation which have led to problems in its application. The second objective of the common frame of reference is to form the basis for further reflection on an optional instrument in the area of European contract law.

The efforts based on this communication were awarded and an Interim Outline Edition of the Draft Common Frame of Reference (DCFR) for European private law was published in 2008, and the definitive Outline Edition 1 in 2009. The full work consists of six volumes and over 6,000 pages. ${ }^{20}$ The Commission launched and sponsored the DCFR project. The CFR was intended as a tool box for future legislation in the field of contract law, and an optional

\footnotetext{
${ }^{18}$ Whole text is available at http://www.jus.uio.no/lm/eu.contract.principles.1998/toc.html

19 The Commission declared with this communication that it is interested in gathering information on the need for wider-reaching Community action in the area of contract law, in particular to the extent that the case-by-case approach might not be able to solve all the problems which might arise.

${ }^{20}$ Principles, Definitions and Model Rules of European Private Law Draft Common Frame of Reference (DCFR) Outline Edition Prepared by the Study Group on a European Civil Code and the Research Group on EC Private Law (Acquis Group) Edited by Christian von Bar, Eric Clive and Hans Schulte-Nölke and Hugh Beale, Johnny Herre, Jérôme Huet, Matthias Storme, Stephen Swann, Paul Varul, Anna Veneziano and Fryderyk Zoll (Sellier, Munich: 2009) european-private-law_en.pdf
} 
instrument in contract law, where the parties to a contract can choose to apply in their relationship.

When looking into the DCFR text, one sees that it exceeded the contract law area and included some civil law concepts such as tort, unjustified enrichment, acquisition and loss of ownership of goods and proprietary security rights in movable assets. Even more, trust, an alien concept to civil law legal systems, is regulated as a separate chapter in the DCFR. Hence, we can easily say that the DCFR is more like a civil code excluding family and inheritance law, rather than a piece of contract law legislation. As Jansen \& Zimmermann state, "The DCFR, obviously, is a comprehensive body of rules systematically covering a central field of private law and intended to be applicable to transnational disputes." (Jansen and Zimmermann, 2010:98)

The DCFR consisted of ten books:

Book I General provisions

Book II Contracts and other juridical acts

Book III Obligations and corresponding rights

Book IV Specific contracts and the rights and obligations arising from them

Book V Benevolent intervention in another's affairs

Book VI Non-contractual liability arising out of damage caused to another

Book VII Unjustified enrichment

Book VIII Acquisition and loss of ownership of goods

Book IX Proprietary security rights in movable assets

Book X Trusts

The DCFR was not enacted in the EU as a civil code and will never be as foreseen. Indeed, this is not what it was intended for. The DCFR was supposed to be a source for specific regulations regarding the private law issues which it dealt with. We observe that it functioned as supposed in the proposal of the CESL. Furthermore, the DCFR is still one of the best academic sources for private law in the EU.

\section{Common European Sales Law}

The DCFR served one of its purposes and was a source to the CESL. (COM (2011) 635 final) The CESL text was based mainly on the DCFR. Most deviations from the DCFR were apparently made to make it more attractive to users without legal expertise, i.e. consumers and politicians acting in the interests of consumers. (Wulf, 2014:18)

The Commission's main economic argument in favour of the CESL was that it would help businesses to avoid the costs associated with having to deal with multiple mandatory provisions of the consumers' home 
jurisdictions. By using the CESL contracting businesses can reduce information costs, i.e. part of the transaction costs for the choice of law in a consumer cross-border transaction." (Wulf, 2014:146)

The proposed CESL was intended to serve as an 'optional instrument', meaning that it would contain a single set of rules, which would exist in parallel to the contract laws of the Member States. Those rules would have the legal force of an EU Regulation, and therefore would be directly and uniformly applicable across the EU. However, their applicability to a concrete contractual relationship would not be automatic, but would depend on the decision of the parties. (Manko, 2015:14)

The strongest point of the CESL was that the proposal was a Regulation, which would provide unification and a possible unified practice all over the EU even though it was an optional instrument leaving its application on the business-to-customer or business-to-business cross-border transactions to the parties to a contract. Hence, the CESL would not change national contract laws but create a new system where parties could opt in. On the other hand, as seen, with the CESL, the scope for unification of the private law in the EU was narrowed down to sale contract from a comprehensive civil code.

It is sad to say that even that optional level of unification could not be achieved as the proposal for the CESL was withdrawn. The proposal for the CESL was listed as item 60 in the Annex of withdrawn proposals in the Work Programme for 2015 to the European Parliament. The reason given for the withdrawal was: "Modified proposal in order to fully unleash the potential of ecommerce in the Digital Single Market". (Clive, 2015)

The CESL consisted of eight parts, 186 articles and two appendixes.

The parts are:

Part I 'Introductory provisions'

Part II 'Making a binding contract'

Part III 'Assessing what is in the contract'

Part IV 'Obligations and remedies of the parties to a sales contract'

Part V 'Obligations and remedies of the parties to a related services contract'

Part VI 'Damages and interest'

Part VII 'Restitution'

Part VIII 'Prescription'

As observed from the content, even though the CESL was designed to regulate cross-border sale contracts, it embraced general contract provisions too because in the EU there is no such legislation including general contract rules. 


\section{Digital Content Supply Contract Directive}

After the CESL was excluded from the work program, the European Commission introduced two proposal Directives: the Proposal for a Directive on certain aspects concerning contracts for the supply of digital content (COM/2015/0634 final) and the Proposal for a Directive on certain aspects concerning contracts for the online and other distance sales of goods (COM/2015/0635 final). Both drafts derived from the CESL text in order to regulate and harmonise online and other distance sale of goods contracts in the EU.

These two directives would require full harmonisation (with only a few exceptions). This means that on the issues within the scope of the Directives, Member States would not be able to provide their consumers with higher levels of consumer protection. Although drafted with the best of intentions, the Directives would result in significant reduction in consumer protection in some Member States. Special care must be taken to ensure that the level of consumer protection - particularly the conformity obligations and remedies - is adequate. (Statement of the European Law Institute, 2016:1)

The instrument chosen for the harmonisation of the digital content supply contract is a 'Directive'. As mentioned in the previous section, this not the best option to build a unified legal structure in the EU. Moreover, it obvious that the level of harmonisation and unification in the EU in private law have been diminished to a specific type of sale contract. That is frustrating. That documents verify that the EU civil code is a dream and not expected to come true in near future.

\section{Principles of European Tort Law}

Tort law constitutes an important area of law of obligations and hence civil law. The European Group on Tort Law published the Principles of European Tort Law, accompanied by a commentary and several translations. (European Group on Tort Law, 2005) It is an academic work and does not have any statutory power and there is no sign that it will be enacted as a legislative document in the EU. What we infer from the statements of Koch is that the only function that these Principles would have is if the EU, in the future, decides to unify the civil law, these Principles may be the source to the tort part of this Code.

The "Principles of European Tort Law" are not intended to serve as a model code, even though drafting them required a wording that often resembles a statutory text. The primary purpose was to present a common framework both for the further development of national laws and for uniform European legislation. Such a framework could avoid a further divergence of piece-meal rule-making on a national as well as the 
European level. Nevertheless, throughout the drafting process, the Principles obviously had to be tested for their potential to serve as a foundation of a future European codification, should it ever happen. (Koch, 2005:191)

As we witnessed later the European Group's Principles of European Tort Law was incorporated in the Draft Common Frame of Reference. (Oliphant, 2009:445)

PETL consists of ten chapters:

Chapter 1. Basic Norm

Chapter 2. Damage

Chapter 3. Causation

Chapter 4. Liability based on fault

Chapter 5. Strict liability

Chapter 6. Liability for others

Chapter 7. Defences in general

Chapter 8. Contributory conduct or activity

Chapter 9. Multiple Tortfeasors

Chapter 10. Damages

To conclude, the only function that the PETL can have in the unification of civil law in the EU would be to form a specific part of the EU civil code.

Directives

The EU generally regulates the consumer law, a part of civil law, by directives. ${ }^{21}$ Below, we will mention some of them, none of which could be deemed as a civil code itself. ${ }^{22}$

${ }^{21}$ The EU currently reviews the directives in consumer law area. The Commission is performing a Fitness Check of EU Consumer and Marketing legislation which covers the following directives:

Directive 2005/29/EC concerning unfair business-to-consumer commercial practices in the internal market (Unfair Commercial Practices Directive);

Directive 1999/44/EC on certain aspects of the sale of consumer goods and associated guarantees (Sales and Guarantees Directive);

Directive 93/13/EEC on unfair terms in consumer contracts (Unfair Contract Terms Directive).

Directive 98/6/EC on consumer protection in the indication of the prices of products offered to consumers (Price Indication Directive);

Directive 2006/114/EC concerning misleading and comparative advertising (Misleading and Comparative Advertising Directive); 
Consumer Rights Directive: It is the Directive 2011/83/EU of the European Parliament and of the Council of 25 October 2011 on consumer rights, amending Council Directive 93/13/EEC and Directive 1999/44/EC of the European Parliament and of the Council and repealing Council Directive 85/577/EEC and Directive 97/7/EC of the European Parliament and of the Council. ${ }^{23}$ This directive repealed the Doorstep Selling Directive ${ }^{24}$ and Distance Selling Directive. ${ }^{25}$ Although the Directive has some effects on property law, it is obvious that it is related to consumer law and it can only be deemed to represent a small part of the prospected EU civil code.

Package Travel Directive: It is the Directive (EU) 2015/2302 of the European Parliament and of the Council of 25 November 2015 on package travel and linked travel arrangements, amending Regulation (EC) No 2006/2004 and Directive 2011/83/EU of the European Parliament and of the Council and repealing Council Directive 90/314/EEC. ${ }^{26}$ Again this Directive only regulates a single contract in the consumer law area.

Unfair Terms Directive: It is the Council Directive 93/13/EEC of 5 April 1993 on unfair terms in consumer contracts. ${ }^{27}$ The Directive is related to consumer law and therefore contract law, a part of civil law.

Timeshare Directive: It is the Directive 2008/122/EC of the European Parliament and of the Council of 14 January 2009 on the protection of consumers in respect of certain aspects of timeshare, long-term holiday product, resale and exchange contracts. ${ }^{28}$ Timeshares are divisions of property entitlements in time, therefore this directive relates to contract and property law

Directive 2009/22/EC on injunctions for the protection of consumers' interests (Injunctions Directive). See http://ec.europa.eu/consumers/consumer_rights/review/index_en.htm for more information.

${ }^{22}$ For the general review of these directives see Akkermans, B. "Common Frame of Reference, The EU Consumer Acquis and European Property Law" presented on 28 November 2008 during the Ius Commune Research School Conference, Workshop Property Law, held in Amsterdam, the Netherlands. https://papers.ssrn.com/sol3/papers.cfm?abstract_id=1626793

${ }^{23} \mathrm{http}$ ://eur-lex.europa.eu/legal-content/EN/TXT/PDF/?uri=CELEX:32011L0083\&rid=1

24 http://eur-lex.europa.eu/LexUriServ/LexUriServ.do?uri=CELEX:31985L0577:en:HTML Council Directive of 20 December 1985 to protect the consumer in respect of contracts negotiated away from business premises (85/577/EEC).

25 Directive 97/7/EC of the European Parliament and of The Council of 20 May 1997 on the protection of consumers in respect of distance contracts. http://eur-lex.europa.eu/legalcontent/en/ALL/?uri=CELEX\%3A31997L0007

${ }^{26} \mathrm{http}: / /$ eur-lex.europa.eu/legalcontent/EN/TXT/?uri=uriserv:OJ.L_.2015.326.01.0001.01.ENG\&toc=OJ:L:2015:326:TOC ${ }^{27} \mathrm{http}: / /$ eur-lex.europa.eu/LexUriServ/LexUriServ.do?uri=CELEX:31993L0013:en:HTML

${ }^{28} \mathrm{http} / / /$ eur-lex.europa.eu/legal-content/EN/ALL/?uri=CELEX:32008L0122 
areas as timeshare is acquired by a contract and the concept of timeshare is a typical property law area. ${ }^{29}$

Unfair Commercial Practices Directive: It is the Directive 2005/29/EC of the European Parliament and of the Council of 11 May 2005 concerning unfair business-to-consumer commercial practices in the internal market and amending Council Directive 84/450/EEC, Directives 97/7/EC, 98/27/EC and 2002/65/EC of the European Parliament and of the Council and Regulation (EC) No 2006/2004 of the European Parliament and of the Council. ${ }^{30}$ This Directive is one of the most important directives regulating the consumer contracts for the goods and services.

Consumer Sales and Guarantees Directive: It is the Directive 1999/44/EC of the European Parliament and of the Council of 25 May 1999 on certain aspects of the sale of consumer goods and associated guarantees. ${ }^{31}$

\section{Research Groups}

In this section, we are going to present the research groups that carry out research activities in the EU for the unification of the civil law or a specific part of it.

\section{The Acquis Group}

The official name of the Acquis Group is 'European Research Group on Existing EC Private Law'. The Acquis Group, which consists of about 40 academics, was founded in 2002. The Acquis Group is part of the Joint Network on European Private Law.

As a reaction on activities of EU institutions in the field of European contract law, the Acquis Group targets a systematic arrangement of existing Community law which will help to elucidate the common structures of the emerging Community private law. For this purpose, the Acquis Group primarily concentrates upon the existing EC private law which can be discovered within the acquis communautaire. The research of the Acquis Group will be published as "Principles of the Existing EC Contract Law".32

This group is one of the study groups that prepared the DCFR. Hans Christoph Grigoleit \& Lovro Tomasic explains the process and their principles in their article:

${ }^{29}$ It is basically defined as the arrangement whereby several joint owners have the right to use a property as a holiday home under a time-sharing scheme.

${ }^{30} \mathrm{http}$ ://eur-lex.europa.eu/LexUriServ/LexUriServ.do?uri=OJ:L:2005:149:0022:0039:EN:

PDF

${ }^{31} \mathrm{http}$ ://eur-lex.europa.eu/legal-content/EN/TXT/PDF/?uri=CELEX:31999L0044

$32 \mathrm{http}: / /$ www.acquis-group.org/ (the website is no longer available.) 
The Acquis Principles (ACQP) are a systematic compilation of model rules and principles derived from the existing EU private law. ... However, the work of the Acquis Group is not intended to formulate the elements of the Common Frame of Reference itself, but to provide the Commission with the genuine European content. These elements will have to be combined with common rules or principles derived from national legal orders and national case-law. (Grigoleit \& Tomasic, 2011)

\section{The Study Group on a European Civil Code}

This group is also one of the study groups that prepared the DCFR. The Study Group on a European Civil Code, established in 1998 as a network of academics from across the EU, follows the working path of the Lando's Group. The Study Group conducts comparative law research in private law in the various legal jurisdictions of the Member States. Its activities are undertaken by Working Teams, operating on a permanent basis with responsibility for research and proposals within the particular fields of private law assigned to them, and by a Coordinating Group, formed by almost 50 professors, which is charged with reviewing the work. ${ }^{33}$

The Study Group published nine books about the unification of European civil law and EU civil code apart from the DCFR: Sales, ${ }^{34}$ Lease of Goods, ${ }^{35}$ Service Contracts, ${ }^{36}$ Commercial Agency, Franchise and Distribution Contracts, ${ }^{37}$ Personal Security, ${ }^{38}$ Benevolent Intervention in Another's Affairs, ${ }^{39}$ Non-Contractual Liability Arising out of Damage Caused to Another, ${ }^{40}$ Unjustified Enrichment, ${ }^{41}$ Acquisition and Loss of Ownership of Goods. $^{42}$

\footnotetext{
33 http://www.sgecc.net/

34 Prepared by Ewoud Hondius, Viola Heutger, Christoph Jeloschek, Hanna Sivesand, Aneta Wiewiorowska (Sellier, Bruylant, Staempfli, Oxford University Press 2008).

35 Prepared by Kåre Lilleholt, Anders Victorin†, Andreas Fötschl, Berte-Elen R. Konow, Andreas Meidell, Amund Bjøranger Tørum (Sellier, Bruylant, Staempfli, Oxford University Press 2007).

${ }^{36}$ Prepared by Maurits Barendrecht, Chris Jansen, Marco Loos, Andrea Pinna, Rui Cascão, Stéphanie van Gulijk (Sellier, Bruylant, Staempfli, Oxford University Press 2006)

37 Prepared by Martijn W. Hesselink, Jacobien W. Rutgers, Odavia Bueno Díaz, Manola Scotton, Muriel Veldmann (Sellier, Bruylant, Staempfli, Oxford University Press 2006)

${ }^{38}$ Prepared by Ulrich Drobnig (Sellier, Bruylant, Staempfli, Oxford University Press 2007)

${ }^{39}$ Prepared by Christian von Bar (Sellier, Bruylant, Staempfli, Oxford University Press 2006)

${ }^{40}$ Prepared by Christian Von Bar (Sellier European Law Publishers (20 July 2009)

${ }^{41}$ Prepared by Stephen Swann (Sellier European Law Publishers (1 April 2010)

42 Prepared by Wolfgang Faber (Author), Brigitta Lurger (Author) Sellier European Law Publishers (28 Mar. 2011)
} 


\section{The European Law Institute}

The European Law Institute, founded in June 2011 as an entirely independent organisation, aims to improve the quality of European law, understood in the broadest sense. It seeks to initiate, conduct and facilitate research, to make recommendations, and to provide practical guidance in the field of European legal development. ${ }^{43}$ According to their manifesto,

The European Law Institute (ELI) is an independent non-profit organisation established to initiate, conduct and facilitate research, make recommendations and provide practical guidance in the field of European legal development. Building on the wealth of diverse legal traditions, its mission is the quest for better law-making in Europe and the enhancement of European legal integration. By its endeavours, ELI seeks to contribute to the formation of a more vigorous European legal community, integrating the achievements of the various legal cultures, endorsing the value of comparative knowledge, and taking a genuinely pan-European perspective. ${ }^{44}$

They are currently conducting five projects, including one in family and succession law and another one in protection of adults.

Association Henri Capitant des amis de la culture juridique française and Société de Législation Comparée

The 'Association Henri Capitant' is a group of lawyers from different countries, who are interested in French culture and legislation. At its foundation in the year 1935 only lawyers from French-speaking countries took part, but in the course of time lawyers from other countries joined. ${ }^{45}$

The Association published European Contract Law Materials for a Common Frame of Reference: Terminology, Guiding Principles, Model Rules. ${ }^{46}$ The book contains the guiding principles and a revised version of the PECL, legal terminology, which are deemed to help to contribute to the final Common Frame of Reference. ${ }^{47}$ We see from the final DCFR text, their contributions are taken into account in drafting the DCFR as they intended. ${ }^{48}$ Each year the

${ }^{43} \mathrm{http}: / /$ www.europeanlawinstitute.eu/

${ }^{44} \mathrm{http}: / /$ www.europeanlawinstitute.eu/about-eli/

45 http://www.henricapitant.org/

46 Produced by Association Henri Capitant des Amis de la Culture Juridique Française and Société de Législation Comparée. Edited by Fauvarque-Cosson and Denis Mazeaud. Prepared by Racine, Sautonie-Laguionie, Tenenbaum and Wicker (Munich 2008).

${ }^{47}$ Produced by Association Henri Capitant des Amis de la Culture Juridique Française and Société de Législation Comparée. Edited by Fauvarque-Cosson and Denis Mazeaud. Prepared by Racine, Sautonie-Laguionie, Tenenbaum and Wicker (Munich 2008) p.XXVIII

${ }^{48} \mathrm{http}$ //ec.europa.eu/justice/contract/files/european-private-law_en.pdf p.11-18 
Association organises an international event on comparative law. The Association publishes Henri Capitant Law Review regularly. ${ }^{49}$

\section{The Trento Common Core Project}

The University of Trento, Italy, hosts the Project. ${ }^{50}$ The key tool of the Common Core of European Private Law Project is the questionnaire on the three principal areas of property, torts, and contracts, which are divided into a number of topics. Each participant, when encharged with the responsibility of editing a particular topic volume, is first required to draft a factual questionnaire and to discuss it in one of the topical sessions during general meetings. (Mattei \& Bussani) The project founder states their goals as:

[w]e are seeking to unearth the common core of the bulk of European private law, i.e., of what is already common, if anything, among the different legal systems of European Union member states." and “...The idea underlying our project is that the best means to achieve an open legal space in Europe is through the creation of a model "European law school" capable of shaping a truly common legal education. (Mattei \& Bussani)

The Project organizes conferences ${ }^{51}$ and publishes books. ${ }^{52}$ In that sense, we can easily say that this Project is one of the most nourishing projects working on the unification of European civil law.

\section{European Private Law Forum}

European Private Law Forum is established at the European University Institute, in Florence, Italy. The Forum's research activities focus on the constitutional dimensions of the private law Europeanisation process; the emergence of transnational private governance arrangements and the role of non-governmental actors in law-making processes; the relationship between market regulation and the Europeanisation of private law; the analysis of external factors affecting the integration process of European private law, and the role of the European judiciary in the Europeanisation process. ${ }^{53}$ European Private Law Forum organises workshops and publishes books. ${ }^{54}$

\footnotetext{
${ }^{49} \mathrm{http}: / /$ www.henricapitant.org/revue/en

${ }^{50} \mathrm{http}: / /$ www.common-core.org/

51 23rd meetinng was held in Torino see http://www.common-core.org/node/163

52 See for the list http://www.common-core.org/node/31

${ }^{53} \mathrm{https}$ ://www.eui.eu/DepartmentsAndCentres/Law/ResearchAndTeaching/ResearchThemes/ EPL/EPLForum

${ }^{54}$ https://www.eui.eu/DepartmentsAndCentres/Law/ResearchAndTeaching/ResearchThemes/ EPL/EPLoutcome
} 
The Research Group on the Economic Assessment of Contract Law Rules (The Economic Impact Group-EIG)

The Joint Network on Common Principles of European Contract Law (CoPECL), a network of excellence, funded under the $6^{\text {th }}$ Framework Program of the EC, was initiated in 2005 and ran until 30 April 2009.

The network consisted of eight research groups, of which TILEC headed the 'Economic Impact Group'. The Economic Impact Group (EIG) is a group of leading academics in the economic analysis of law. Its task was to study and assess the Draft Common Frame of Reference (DCFR) from an economic perspective. (The Research Group website)

The Economic Impact Group within the CoPECL project provided an evaluative work of the DCFR, which was published as a book later. (Chirico \& Larouche, 2010) However, it could not be taken into account in the formulation of the model rules from the earliest stages indeed. (DCFR, 2009:75)

\section{The Academy of European Law (ERA)}

Founded upon the initiative of the European Parliament, the Academy of European Law began work in Trier in March 1992. (The Academy of European Law website)

The task of the Academy of European Law Trier shall be to enable individuals and authorities involved in the application and implementation of European law in Member States and in other European States interested in close co-operation with the European Union to gain a wider knowledge of European law, in particular European Union law and its application and to make possible a mutual and comprehensive exchange of experiences. The Academy shall pursue this objective by organising courses, conferences, seminars and specialist symposia, particularly for the purposes of continuing vocational training, by issuing publications and by providing a forum for discussions. (Statute §3Objectives)

\section{Commission on European Family Law}

The Commission on European Family Law (CEFL) was established on the $1^{\text {st }}$ of September, 2001. The CEFL consists of approximately 26 distinguished experts in the field of family and comparative law from all EU Member States and other European countries. The main objective of the CEFL is to launch a pioneering theoretical and practical exercise in relation to the harmonization of family law in Europe. (CEFL website) They have drafted three set of principles: Principles on Divorce and Maintenance between Former Spouses, Principles on Parental Responsibilities, and Principles on Property Relations between Spouses. 


\section{The European Group on Tort Law}

The European Group on Tort Law (formerly also called "Tilburg Group") is a group of scholars in the area of tort law established in 1992. The group meets regularly to discuss fundamental issues of tort law liability as well as recent developments and the future directions of the law of tort. The Group has drafted a collection of Principles of European Tort Law (PETL). According to the official website "The European Group on Tort Law aims to contribute to the enhancement and harmonization of tort law in Europe through the framework provided by its Principles of European Tort Law (PETL) and its related and ongoing research, and in particular to provide a principled basis for rationalisation and innovation at national and EU level." (PETL website )

\section{Accademia dei giusprivatisti europei}

The Academy of European Private Lawyers, known as Gandolfi Group was established in Pavia on $9^{\text {th }}$ of November, 1992. According to the Statute of the Academy, "its aim is to contribute, through scientific research, to the unification and the future interpretation and enforcement of private law in Europe, in the spirit of the community conventions", and also "to promote the development of a legal culture leading to European unification". ${ }^{55}$ The major work of the group is their books European Contract Code Book ${ }^{56}$ and II. ${ }^{57}$

\section{Joint Network on European Private Law (COPECL)}

Joint Network on European Private Law (CoPECL) ran from $1^{\text {st }}$ of May, 2005 to $30^{\text {th }}$ of April, 2009 with EU financial contribution under the Network of Excellence funding scheme. The objectives of this proposal were:

1. Delivery of a "Common Frame of Reference" The Network will deliver a proposal for the "Common Frame of Reference" for European contract law as de-scribed in the Commission's Action Plan (COM [2003] 68 final). 2. Overcoming Research Fragmentation in the European Research Area The European research landscape is currently fragmented into different international groups which carry out their research independently. 3. Guidance to Legislators, Legal Practice and Academics The CoPECL will benefit legislators, legal practitioners and academics. 4. Durable Research Integration and Dissemination of Knowledge The Network will not only lead to a functional co-operation of leading European research groups; it will furthermore create the framework for continuing and durable research. ${ }^{58}$

\footnotetext{
$55 \mathrm{http}: / /$ www.eurcontrats.eu/acd2/general-information/ See for the list of publications: http://www.eurcontrats.eu/site2/newdoc/Note\%20bibliografiche.pdf $56 \mathrm{http}: / /$ www.eurcontrats.eu/site2/newdoc/Norme\%20_Libro\%20I-inglese_pdf

${ }^{57} \mathrm{http}: / /$ www.eurcontrats.eu/site2/newdoc/Norme\%20_LibroII-inglese_.pdf

$58 \mathrm{http}: / /$ cordis.europa.eu/project/rcn/75707_en.html
} 
Eighteen member expert groups, including The Study Group on a European Civil Code; The Research Group on the Existing EC Private Law, or "Acquis Group"; The Project Group on a Restatement of European Insurance Contract Law, or "Insurance Group"; The Association Henri Capitant together with the Société de Législation Comparée and the Conseil Supérieur du Notariat; The Common Core Group; The Research Group on the Economic Assessment of Contract Law Rules, or "Eco-nomic Impact Group", participated to examine the possibility of creating an 'optional European contract law' on the basis of the DCFR.

According to the final report of 'Final Report Summary - COPECL' (Joint Network on European Private Law): "The six-volume 'Draft Common Frame of Reference (DCFR) for European Private Law' which was elaborated together with a corona of evaluative works on, e.g. terminology, underlying principles and economic aspects is the core objective achieved by the COPECL Network of Excellence (NoE)." 59

\section{Conclusion}

In the light of above explanations, we believe that to prepare a draft for an ECC, which would be accepted by the Members States, could not be achieved in the near future. As observed from all the presented endeavours for a unified ECC, nothing remarkable is achieved so far. Furthermore, it is witnessed that the idea of a unified ECC has been diminished to a unification of a single contract in the EU; not even the sale contract but digital content supply contract. Indeed, the European Union itself is in crisis now and has more immediate problems to solve; such as the refugee crisis and the Brexit process. Moreover, the challenges are not limited to political subjects, but also economic. Some claim that Eurozone may shrink and collapse soon. (Express, 2017) In such an environment, one cannot expect that the EU would demonstrate a strong will to unify its private law. This is not realistic. As Zimmermann states:

All in all, therefore, the auspices for a European Code of Contract Law, let alone a Civil Code, are far from ideal. There is no common language in which it could be drafted. There is no Supreme Court in private law matters which could effectively ensure its uniform application. There is not yet a sufficiently strong European legal scholarship that could sustain it. Some arguments can be advanced in favour of a European code but they are fairly weak, and they lack any emotional appeal. In particular, there is not yet a strong feeling of European identity (comparable to the feeling of national identity in the 19th century) that would give wings to 
such endeavour. And there is no sense of crisis that would make a codification appear indispensable. (Zimmermann, 2012)

The reader would remember Michaels's approach towards the ECC, which pronounce that Europeanization and hence the ECC is supported as long as the French civil code is accepted as the new ECC. (Michaels, 2012:277) It is not a remote possibility to assume that the other nations could assert the same for their codes. With these patriotic and nationalist views on the EU civil code, it is not difficult to reach the above mentioned conclusion: the ECC is a dream which is unlikely to come true soon.

There are some optimists and romantics like Schmid, who enthusiastically waits for that dream to realise. He states that:

[...] a European Civil Code could lead the European Union to a whole new level of togetherness and international recognition; an overall brighter future. In this future, a European citizen would have the same level of protection whether, for example, his car accident happened in Austria or Italy. In this future, all the European scholars would combine their efforts to develop the European civil law. It would be the future of even fewer borders in Europe." (Schmid, 2012:293)

However, the truth is so virulent that the reality surfaces soon:

"Yet, this brighter future is a long way down a road that has to be walked in many small steps. It will take a long time and is surely not going to be easy. All that can be hoped is that whether the decision if the vision of an European Civil Code becomes reality will not be a purely political one and the ambitious goals will not be sold in the political process of finding compromises" (Schmid, 2012:293) ${ }^{60}$

The efforts for an EU civil code started with the harmonization of law of obligations and then the work was expanded on property law and trust. After debates, EU decided to narrow it down to a one single type of contract, namely 'sale contract'. However, a consensus could not be reached and then the unification efforts focused on one type of sale contracts, namely 'digital content supply contracts'. This is frustrating, especially considering that a comprehensive civil code should include all the above mentioned five areas of civil law. Despite some optimistic anticipation, based on the deliberated arguments, we believe that to draw and enact a common comprehensive civil code in the EU currently seems impossible to achieve due to various reasons,

${ }^{60} \mathrm{He}$ is concerned that the EU civil code would share the same destiny with the EU constitution. "At the same time, future steps should be taken carefully in order not to endanger the entire project at this still early stage by giving its opponents the possibility to form an alliance against the European Civil Code based on unfounded anxiety-creating bustle-arguments. Such a scenario has already led to the death of a European Constitution...." (Schmid, 2012:293) 
inter alia, lack of will of the Member States, methodological challenges, the constitutional restrictions of EU law and unfavourable political and economic climate.

Despite our prediction that a unified EU civil code would not be achieved soon, the efforts towards the codification of the EU civil law continues incessantly in legal academic life, even though the EU no longer demonstrates the passion to unify the civil law entirely in the EU. 


\section{References:}

A Digital Single Market Strategy for Europe COM (2015) 192 final, $<\mathrm{http}$ ://ec.europa.eu/priorities/digital-single-market/>.

Akkermans, B., (2008) "Common Frame of Reference, the EU Consumer Acquis and European Property Law" presented at the Ius Commune Research School Conference, "Workshop Property Law", Amsterdam, the Netherlands, 28 November, <https://papers.ssrn.com/sol3/papers.cfm? abstract_id $=1626793>$.

Apaydın, E., (2016) “Common Law'da Trust Kavramı ve Civil Law'da Trust Alanında Güncel Gelişmeler” Legal Hukuk Dergisi, (14): 1789-838.

Apaydın, E., (2013) "Satım Hukuku Özelinde Uluslararası Sözleşme Hukukunun Birleştirilmesi Çalışmalarının Kronolojisi” (Prof. Dr. Aydın Zevkliler'e Armağan) Journal of Yasar Universitesi, 8(9): 201-74.

CEFL website $<$ http://ceflonline.net/history/ $>$.

Chirico, F. \& Larouche, P. (2010) Economic Analysis of the DCFR: The Work of the Economic Impact Group within CoPECL, (Sellier European Law publishers).

Clive, E. (2015) "Proposal for a Common European Sales Law withdrawn" European Private Law News Website, $<$ http://www.epln.law.ed.ac.uk /2015/01/07/proposal-for-a-common-european-sales-law-withdrawn/>.

Collins, H. (2007) "Why Europe Needs a Civil Code: European Identity and the Social Model", <https://www.courdecassation.fr/IMG/File/pdf_2007/26-012007/26-01-2007_why_civil_code.pdf.>.

Communication from the Commission to the European Parliament, the Council, the European Economic and Social Committee and the Committee of the Regions - First report on the implementation of the Framework Action: "Updating and simplifying the Community acquis" COM (2003) 71 final.

Commission Work Programme (2015) <http://ec.europa.eu/atwork/pdf/cwp 2015_withdrawals_en.pdf>.

Communication from the Commission to the Council and the European Parliament on European Contract Law 11.07.2001 COM (2001) 398 final.

Communication from the Commission to the European Parliament and the Council, European Contract Law and the revision of the acquis: the way forward, COM (2004) 651 final.

Communication from the Commission to the European Parliament and the Council "A More Coherent European Contract Law - An Action Plan" (2003/C 63/01). 
Communication from the Commission to the European Parliament and the Council - A More Coherent European Contract Law (COM/2003/0068) final.

CoPECL website $<$ http://www.copecl.eu/>.

Craig, P. (2012) "Subsidiarity: A Political and Legal Analysis", Journal of Common Market Studies, (50): 72-103.

Craig, P. and de Búrca, G. (2011) EU Law - Text, Cases and Materials, $5^{\text {th }}$ edn, (Oxford: OUP).

European Commission Green Paper on Policy Options for Progress towards a European Contract Law for Consumers and Businesses COM (2010) 348 final (Jul. 1, 2010).

European Group on Tort Law (2005) "Principles of European Tort Law - Text and Commentary", (Verlag Österreich, Vienna) <http://civil.udg.edu/php/ biblioteca/items/283/PETL.pdf $>$.

Flaminio Costa $v$ ENEL [1964], ECJ, 15 July 1964, Case 6/64, ECR 1.

Germain, C. M. (2016) "CISG Language and Translation Issues", <https:// papers.ssrn.com/sol3/papers.cfm?abstract_id $=2770123>$.

Grant, W., Matthews, D. and Newell, P. (2000) The Effectiveness of European Union Environmental Policy, (London: Macmillan Press).

Grigoleit, H.C. \& Tomasic, L. (2012) “Acquis Principles” Basedow, J., Hopt, K.J., and Zimmermann, R. (ed.s), Max Planck Encyclopaedia of European Private Law, (Oxford: OUP)

Hesselink, M. W. (2004) "The Politics of a European Civil Code" European Law Journal, 10 (6): 675-97.

The Express Website (2017) by Osborne, S., "Eurozone may shrink and collapse: Shock report reveals what business leaders REALLY think" (22 May 2017), <http://www.express.co.uk/news/world/807579/Eurozonecrisis-European-business-leaders-survey-EU-economy-McKinsey-GlobalInstitute>.

The Independent Website (2016) by Guarascio, F. "EU's Brexit negotiator demands all talks are conducted in French" (21 October 2016) $<\mathrm{http}$ ://www.independent.co.uk/news/world/europe/brexit-negotiator-talksfrench-michel-barnier-negotiation-insists-eu-article-50-conducteda7373556.html>.

Jansen N., and Zimmermann, R. (2010) "European Civil Code in all but Name: Discussing the Nature and Purposes of the Draft Common Frame of Reference" C. L. J. 69(1), p.98-112. 
Joint Network on European Private Law (CoPECL: Common Principles of European Contract Law), Network of Excellence under the 6th EU Framework Programme for Research and Technological Development, Priority 7 - FP6-2002-CITIZENS-3, Contract N 513351 (co-ordinator: Prof. Hans Schulte-Nölke, Osnabrück) <http://cordis.europa.eu/result/rcn/ 51949 en.html>.

Koch, B. A. (2005) "The "European Group on Tort Law" and Its "Principles of European Tort Law"', The American Journal of Comparative Law, 53 (1): 189-205.

Kunda, I. \& Marinho, C. Practical Handbook on European Private International Law, $<$ http://old.just.ro/LinkClick.aspx?fileticket $=\mathrm{Mx} \% 2$ BaR1qqfmU\%3D\&tabid $=2285>$.

Lando, O. (1999) "The rules of European contract law" in "The Private Law Systems in The EU: Discrimination on Grounds of Nationality and the Need for a European Civil Code" Working Paper Legal Affairs Series JURI103 $\mathrm{EN},<$ https://www.cisg.law.pace.edu/cisg/biblio/lando2.html $>$.

Lando, O., \& Beale, H. (Eds), (2000) Principles of European Contract Law, Parts I And II .

Lando, O., Clive, E., Prüm, A, \& Zimmermann, R. (eds), (2003) Principles of European Contract Law, Part III.

Lando, O. (1977) "The Contribution of Comparative Law to Law Reform by International Organizations" The American Journal of Comparative Law, 25 (4): 641-657.

Lapuente, S. C. (2002) "The Hypothetical "European Civil Code":Why, How, When?", ERA Forum, pp.89-99, <https://link.springer.com/content/ pdf/10.1007/BF02817591.pdf $>$.

Mańko, R. (2015) "Contract law and the Digital Single Market" European Parliamentary Research Service Members' Research Service, September 2015, <http://www.europarl.europa.eu/RegData/etudes/IDAN/2015/568322/ EPRS_IDA\%282015\%29568322_EN.pdf>.

Mattei, U. \& Bussani, M. "The Trento Common Core Project" $<$ http://www.common-core.org/node/9>.

Michaels, R. (2012) "Code vs. Code: Nationalist and Internationalist Images of the Code çivil in the French Resistance to a European Codification", European Review of Contract Law, (8): 277-95.

Monti, M. (9 May 2010) "A New Strategy for the Single Market - At the Service of Europe's Economy and Society", Report for the European Commission. 
Oliphant, K. (2009) "European Tort Law: A Primer for the Common Lawyer" Current Legal Problems, (62): 440-77.

PETL website $<$ http://www.egtl.org/>.

The Study Group on an European Civil Code and the Research Group on EC Private Law (Acquis Group) (2009) Principles, Definitions and Model Rules of European Private Law Draft Common Frame of Reference (DCFR) Outline Edition Christian von Bar, Eric Clive and Hans Schulte-Nölke and Hugh Beale, Johnny Herre, Jérôme Huet, Matthias Storme, Stephen Swann, Paul Varul, Anna Veneziano and Fryderyk Zoll (ed.s) (Sellier: Munich).

Proposal for a Regulation of the European Parliament and of the Council on a Common European Sales Law CESL COM (2011) 635 final. 2011/0284 (COD).

Resolution A2-157/89, OJ EC 1989, C 158/400.

Resolution A3-0329/94 (OJ C 205, 25.7.1994, p. 518).

Resolution B5-0228, 0229 - 0230 / 2000 (OJ C 377, 29.12.2000, p. 323).

Rutgers, J. W. (2010) "European Competence and a European Civil Code, a Common Frame of Reference or an Optional Instrument" VU University Amsterdam, Faculty of Law, January 26, <https://papers.ssrn.com /sol3/papers.cfm?abstract_id=1542533>

Schmid, D. (2012) “(Do) We Need a European Civil Code (?)”Annual Survey of International \& Comparative Law, 18 (1): 270-74, <http://digitalcommons. law.ggu.edu/annlsurvey/vol18/iss1/11>.

Schmidtchen, D. (2002) "Lex Mercatoria und die Evolution des Rechts", "Vereinheitlichung Und Diversität Des Zivilrechts in Transnationalen Wirtschaftsräumen" in 1, 9 (Claus Ott \& Hans-Bernd Schäfer eds.,) (translated by Gralf-Peter Calliess ) CALLIESS, Gralf- Peter, "The Making of Transnational Contract Law" (2007) 14 Indiana Journal of Global Legal Studies 469.

Statement of the European Law Institute on the European Commission's Proposed Directive on the Supply of Digital Content to Consumers COM (2015) 634 final, <http://www.europeanlawinstitute.eu/fileadmin/ user_upload/p_eli/Publications/ELI_Statement_on_DCD.pdf $>$.

Statute 3

Objectives $<$ https://www.era.int/cgibin/cms? SID=a68fb1eea000330be9737bf86851d3b387a2e3aa0056024721 2757\&amp; sprache=en\&amp; bereich=artikel\&amp; aktion=detail\&amp; persistant_variant $=\% 2 \mathrm{FAbout} \% 20 \mathrm{ERA} \% 2 \mathrm{FThe} \% 20$ Foundation $\% 2 \mathrm{FStatut}$ e\&amp; template_variant3=Statute\&amp;idartikel=100451>. 
TEU, Consolidated version of the Treaty on European Union, OJ C 326, 26.10.2012.

TFEU, Consolidated version of the Treaty on the Functioning of the European Union, OJ C 326, 26.10.2012.

The Academy of European Law website <https://www.era.int/cgibin/cms?_SID=17f5569560ccec664068ad5087811302d122620a005602466 18310\&amp; sprache=en\&amp; bereich=artikel\&amp; aktion=detail\&amp ; persistant_variant $=\% 2$ FAbout $\% 20$ ERA $\% 2$ FThe $\% 20$ Foundation $\% 2$ FHisto ry\&amp; template_variant3=History\&amp;idartikel=100452>.

The Research Group on the Economic Assessment of Contract Law Rules (The Economic Impact Group (EIG) website <https://www.tilburguniversity.edu/ research/institutes-and-research-groups/tilec/research/projects-networks/ past-projects/copecl/>.

Tekin Apaydın, D. (2014) "The EU Regulation on After-sales Services in the Consumer Rights Directive: Missed or Seized the Opportunity?" MÜHFHAD 20 (3): 3-25.

Von Bar, C. (2009) Principles, Definitions and Model Rules of European Private Law: Draft Common Frame of Reference (DCFR) (Sellier European Law Publishers).

Wulf, A. J. (2014) Institutional Competition of Optional Codes in European Contract Law Eur J Law Econ (Springer).

Zimmermann, R. (2012) "Codification - The Civilian Experience Reconsidered on the Eve of a Common European Sales Law" Max Planck Private Law Research Paper No. 12/30 ERCL 8(4): 367-399. 